Jurnal Ners Volume 4 Nomor 1 Tahun 2020 Halaman 13 - 20

JURNAL NERS

Research \& Learning in Nursing Science

http://journal.universitaspahlawan.ac.id/index.php/ners

\title{
HUBUNGAN OBESITAS DENGAN KEJADIAN HIPERTENSI PADA MASYARAKAT DI DESA AIR TIRIS WILAYAH KERJA UPTD PUSKESMAS KAMPAR TAHUN 2019
}

\author{
Yenny Safitri \\ Program Studi Sarjana Keperawatan \\ Universitas Pahlawan Tuanku Tambusai \\ yennysafitri37@yahoo.co.id
}

\begin{abstract}
Abstrak
Hipertensi masalah kesehatan yang sering ditemukan di tengah masyarakat dan mengakibatkan angka kesakitan yang tinggi. Banyak faktor yang memicu terjadinya hipertensi, salah satunya adalah obesitas. Obesitas terjadi karena pola makan dan gaya hidup yang tidak sehat. Penelitian ini bertujuan untuk mengetahui Hubungan Obesitas Dengan Kejadian Hipertensi Pada Masyarakat di Desa Air Tiris Wilayah Kerja UPTD Puskesmas Kampar Tahun 2019. Desain penelitian yang digunakan yaitu analytic dengan rancangan case control. Sampel dalam penelitian ini penderita hipertensi yaitu 52 kasus dan 52 kontrol dengan tehnik pengambilan sampel sistematik random sampling. Penelitian ini dilakukan pada tanggal 13-18 April 2020 dengan mengunakan lembar checklist. Pengolahan data menggunakan uji chi square. Hasil penelitian di dapatkan bahwa ada hubungan yang signifikan antara obesitas dengan kejadian hipertensi pada masyarakat di Desa Air Tiris Wilayah Kerja UPTD Puskesmas Kampar Tahun 2019 dengan nilai p-value $=0.004<0.05$. Berdasarkan hasil penelitian ini disarankan kepada responden agar dapat mengontrol tekanan darah dengan memperbaiki gaya hidup yang kurang baik seperti pola makan yang tidak sehat dan kurang olahraga.
\end{abstract}

\section{Kata Kunci: Obesitas, Kejadian Hipertensi}

$\triangle$ Corresponding author :

Address : Jl. Tuanku Tambusai No. 23 Bangkinang

Email : yennysafitri37@yahoo.co.id

Phone : 085265460467 


\section{PENDAHULUAN}

Hipertensi merupakan penyebab kematian nomor tiga setelah stroke dan tuberculosis, yakni mencapai $6,7 \%$ dari populasi kematian pada semua umur di Indonesia. Hipertensi disebut sebagai pembunuh senyap karena gejalanya sering tanpa keluhan. Biasanya penderita tidak mengetahui kalau dirinya mengidap hipertensi dan baru diketahui kalau dirinya mengidap hipertensi setelah terjadi komplikasi (Depkes RI, 2018).

Hipertensi atau tekanan darah tinggi merupakan suatu peningkatan abnormal tekanan darah dalam pembuluh darah arteri secara terus menerus lebih dari satu periode.

Hipertensi menambah beban kerja jantung dan arteri yang bila berlanjut dapat menimbulkan

kerusakan jantung dan pembuluh darah (Udjianti, 2011).

Penyebab hipertensi dapat dibedakan menjadi 2, yaitu yang dapat diubah dan yang tidak dapat diubah. Faktor yang tidak dapat diubah antara lain usia, jenis kelamin atau gender, suku/ras. Penyebab hipertensi yang dapat diubah antara lain berat badan, aktivitas fisik, stres, kebiasaan merokok, minum alkohol,dan asupan makan tidak sehat

Kesalahan masyarakat modern yang berkontribusi meningkatkan tekanan darah yaitu merokok, penyalahgunaan alkohol, stres, tidak beraktivitas fisik, kelebihan asupan natrium, asupan kalori berlebihan yang menyebabkan obesitas serta kurangnya asupan kalium terutama dari sayur dan buah segar (Hardiansyah\& Supariasa, 2017).

Gaya hidup masyarakat saat ini sudah mengarah pada gaya hidup modern yang ditandai oleh pola makandengan ciri tinggi karbohidrat, tinggi lemak, dan rendah disertai dengan aktivitas fisik kurang gerak(sedentary). Berbagai fasilitas transportasi dan teknologi informasi sangat memanjakan masyarakat.Pada individu obesitas terlihat peningkatan tekanan darah dan cardiac output dibandingkan yang tidak obesitas (Hardiansyah\& Supariasa, 2017).
Kelebihan berat badan dan obesitas merupakan faktor resiko beberapa penyakit degeneratif dan metabolik.Obesitas sebagai faktor resiko penyakit jantung koroner dianggap merupakan faktor yang independen, artinya tidak dipengaruhi oleh faktor resiko yang lain. Seorang pria dapat dianggap telah menderita obesitas apabila jumlah lemaknya telah melebihi $25 \%$ dari berat badan total dan $30 \%$ bagi wanita atau suatu kriteria yang praktis dan paling sering digunakan adalah apabila berat badan telah melebihi $120 \%$ dari berat badan ideal. Tekanan darah akan meningkat seiring dengan bertambahnya umur seseorang. Tekanan darah tersebut akan lebih besar pada individu dengan riwayat keluarga hipertensi, kelebihan berat badan dan mempunyai kecenderungan stres emosional yang tinggi (Mahan, 2012).

Hipertensi yang tidak mendapatkan penanganan yang baik akan menyebabkan komplikasi stroke, penyakit jantung koroner, gagal ginjal. Kerusakan organ target akibat komplikasi hipertensi akan tergantung kepada besarnya peningkatan tekanan darah dan lamanya kondisi tekanan darah yang tidak terdiagnosis dan tidak di obati. Organ organ tubuh yang menjadi target antara lain, otak, mata, ginjal, dan jantung, dan dapat juga berakibat kepada pembunuh arteri perifer itu sendiri (Kemenkes , 2017).

Berdasarkan hasil utama Riskesdas pada tahun 2018, di Indonesia prevalensi hipertensi pada penduduk umur 18 tahun ke atas adalah sebesar $34,1 \%$. Sedangkan prevalensi penyakit jantung adalah sebesar $1,5 \%$, prevalensi untuk penyakit stroke adalah sebesar 10,9\%, dan untuk prevalensi penyakit gagal ginjal kronis adalah sebesar 19,3\% (Hasil Utama Riskesdas, 2018).

World Health Organization(WHO) menyebutkan jumlah penderita hipertensi akan terus meningkat seiring dengan jumlah penduduk yang bertambah pada tahun 2025 mendatang, diperkirakan sekitar 29\% warga dunia terkenan hipertensi. WHO menyebutkan negara ekonomi berkembang memiliki penderita hipertensi sebesar $40 \%$ sedangkan negara 
maju hanya 35\%, kawasan Afrika memegang posisi puncak penderita hipertensi, yaitu sebesar $40 \%$. Kawasan Amerika sebesar 35\% dan Asia tenggara $36 \%$.

Kawasan Asia penyakit ini telah membunuh 1,5 juta orang setiap tahunnya. Hal ini menandakan satu dari tiga orang menderita hipertensi (Adib, 2009).

Berdasarkan hasil utama Riskesdas tahun 2018 bahwa prevalensi obesitas di Indonesia usia >18 tahun semakin meningkat, pada tahun 2007 prevalensi obesitas sebesar 10,5\%, pada tahun 2013 prevalensi obesitas sebesar $14,8 \%$, dan meningkat di tahun 2018 menjadi 21,8\% (Hasil Utama Riskesdas, 2018).

Puskesmas kampar merupakan salah satu puskesmas yang berada di kabupaten kampar dengan jumlah penduduk 44,546 orang.Puskesmas kampar memiliki wilayah kerja yang terdiri dari 18 desa, salah satunya Desa Air Tiris yang memiliki jumlah penduduk 6,122 orang.

Total penduduk pada usia $>15$ tahun di wilayah kerja puskesmas se-kabupaten kampar sebanyak 555,089 orang. Telah dilakukan pemeriksaan obesitas sebanyak 76,519 orang. Total yang dilakukan pemeriksaan obesitas sebanyak 12,666 orang yang mengalami obesitas. Dengan penderita berjenis kelamin perempuan sebanyak 8,039 orang dan 4,627 untuk jenis kelamin laki laki.

Menurut data Dinas Kesehatan Kabupaten Kampar kasus hipertensi termasuk kasus yang cukup tinggi, dilaporkan bahwa jumlah penderita hipertensi pada tahun 2018 sebanyak 36,546 kasus dengan prevalensi $12 \%$ dari rekapitulasi seluruh penyakit terbanyak tahun 2018. Hipertensi termasuk urutan penyakit nomor dua terbesar setelah nasafaringitis akut sebesar 69,732 kasus di Kabupaten Kampar.

Berdasarkan data dapat dilihat bahwa telah dilakukan pemeriksaan hipertensi pada usia>15 tahun sebanyak 6,820 orang dan di dapatkan penderita hipertensi sebanyak 864 orang. Desa Air Tiris merupakan desa dengan jumlah kasustertinggi yang menderita hipertensi dari 18 desa sebanyak 95 orang penderita hipertensi. Jumlah penderita hipertensi di wilayah kerja UPTD Puskesmas Kampar pada bulan Januari - Mei sebanyak 241 orang. Sedangkan jumlah penderita obesitas pada bulan Januari - Mei tahun 2018 sebanyak 414 orang, jumlah penderita obesitas pada bulan Januari - Maret 2019 sebanyak 514 orang.

Berdasarkan hasil survei pendahuluan yang peneliti lakukan, didapatkan bahwa dari 10 orang masyarakat diDesa Air Tiris Wilayah Kerja UPTD Puskesmas Kampar terdapat 8 orang dari mereka yang mengalami hipertensi, 2 orang yang tidak mengalami hipertensi dan 6 orang yang mengalami obesitas, 4 orang yg tidak mengalami obesitas.

Berdasarkan latar belakang diatas penulis tertarik melakukan penelitian mengenai “ Hubungan Obesitas Dengan Kejadian Hipertensi Pada Masyarakat Di Desa Air. Tiris Wilayah Kerja UPTD Puskesmas KamparTahun 2019

\section{Rumusan Masalah}

Bedasarkan uraian dalam latar belakang masalah di atas, maka dapat dirumuskan permasalahannya sebagai berikut “ Apakah Ada Hubungan Obesitas Dengan Kejadian Hipertensi Pada Masyarakat Di Desa Air Tiris Wilayah Kerja UPTD Puskesmas Kampar Tahun 2019 ?

\section{Tujuan penelitian}

Tujuan umum

Mengetahui Hubungan Obesitas dengan Kejadian Hipertensi pada Masyarakat di Desa Air Tiris Wilayah Kerja UPTD Puskesmas Kampar Tahun 2019.

Tujuan khusus

a. Mengetahui distribusi frekuensi kejadian obesitas pada masyarakat di Desa Air Tiris Wilayah Kerja UPTD Puskesmas Kampar Tahun 2019.

b. Mengetahui distribusi frekuensi kejadian hipertensi pada masyarakat diDesa Air TirisWilayah Kerja UPTD Puskesmas Kampar Tahun 2019. 
c. Mengetahui hubungan obesitas dengan hipertensi pada masyarakat di Desa Air Tiris Wilayah Kerja UPTD Puskesmas Kampar Tahun 2019.

\section{METODE PENELITIAN}

\section{Desain Penelitian}

Desain yang digunakan dalam penelitian ini adalah analytic dengan rancangan casecontrol yang bertujuan untuk mengetahui hubungan obesitas terhadap kejadian hipertensi pada masyarakat di Desa Air Tiris Wilayah Kerja UPTD Puskesmas Kampar Tahun 2019.

\section{Tempat dan Waktu Penelitian}

1. Tempat penelitian Penelitian ini dilakukan di Desa Air Tiris Wilayah Kerja UPTD Puskesmas Kampar.

2. Waktu penelitian Penelitian ini dilakukan pada tanggal 13-14 April 2020

\section{Populasi dan Sampel Penelitian Populasi}

a. Kasus

Seluruh penderita hipertensi yang berjumlah 52 responden di Desa Air TirisWilayah Kerja UPTD Puskesmas Kampar Tahun 2019.

\section{b. Kontrol}

Bukan penderita hipertensi yaitu gastritis, ispa, dispepsia, dermatitis,mialgia dan TB paru yang berjumlah 308 responden di Desa Air Tiris Wilayah Kerja UPTD Puskesmas Kampar Tahun 2019.

\section{Sampel}

Sampel dalam penelitian ini menggunakan perbandingan 1:1.

\section{a. Sampel kasus}

Sampel kasus dalam penelitian ini adalah penderita hipertensi sebanyak 52 orang.

b. Sampel kontrol
Sampel kontrol dalam penelitian ini adalah yang bukan penderita hipertensi sebanyak 52 orang.

\section{Teknik Pengambilan Sampel}

a. Sampel kasus

Teknik pengambilan sampel kasus dalam penelitian ini menggunakan teknik total sampling

b. Sampel kontrol

Teknik pengambilan sampel kontrol pada penelitian ini menggunakan teknik sistematik random sampling

c. Jumlah sampel

Keseluruhan sampel yaitu sampel kasus 52 ditambah dengan sampel kontrol 52 kasus berjumlah 104 sampel.

\section{Kriteria Sampel}

a. Kriteria Sampel kasus

1) Kriteria Inklusi

a) Semua penderita hipertensi yang memuat variabel yang di teliti seperti mengalami obesitas yang tercatat di Rekam Medis Puskesmas Kampar Tahun 2019

b) Responden memiliki data lengkap, tidak rusak sesuai dengan kriteria penelitian.

2) Kriteria Eksklusi

a) Penderita hipertensi yang memiliki variabel yang dibutuhkan dalam penelitian tetapi rekam medis tersebut tidak lengkap (rusak, tidak dapat dibaca dan hilang). Sesuai dengan variabel yang diteliti sehingga harus dikeluarkan dan tidak bisa dijadikan sampel lagi.

b. Kriteria sampel kontrol

1) Kriteria Inklusi

a) Responden yang tidak hipertensi yang tercatat di Rekam Medis Puskesmas Kampar Tahun 2019.

2) Kriteria Eksklusi

a) Masyarakat yang tidak mengalami hipertensiyang tercatat di Rekam Medis Tahun 2019 yang mempunyai data yang 
tidak lengkap sesuai dengan variabel yang diteliti.

\section{Metode pengumpulan data}

Metode pengumpulan datayang dilakukan dalam penelitian ini adalah data sekunder dengan mengunakan lembar cheklist.

\section{Prosedur pengumpulan data}

Data penelitian merupakan data sekunder yang diperoleh dari Medical Record Puskesmas Kampar pada tahun 2019. Metode pengumpulan data yaitu pencatatan.

\section{Analisa Data}

Analisa bivariat digunakan untuk meliihat hubungan antara variabel independen dengan variabel dependen. Analisa bivariat akan menggunakan uji Chi-Square $\left(\mathrm{X}^{2}\right)$ dengan menggunakan tingkat kepercayaan $95 \%$

\section{HASIL PENELITIAN}

Penelitian ini dilakukan pada tanggal 13-14 April 2020 di Puskesmas Kampar, dengan jumlah sampel 52 (kasus) dan 52 (kontrol). Data yang diambil pada penelitian ini meliputi obesitas (variabel independen) dan kejadian hipertensi (variabel dependen). Dari hasil pengumpulan data disajikan sebagai berikut: Berdasarkan Tabel 4.1 di atas dapat dilihat bahwa pasien yang tercatat di rekam medis Puskesmas Kampar Berdasarkan Tabel 4.2 diatas diketahui hasil tabulasi silang (crosstabs) antara hubungan obesitas dengan kejadian hipertensi pada masyarakat di desa Air Tiris wilayah kerja UPTD Puskesmas Kampar menunjukkan bahwa dari 52 responden kelompok kasus (hipertensi), terdapat 11 responden $(41,5 \%)$ diantaranya tidak obesitas, dan dari 52 responden kelompok kontrol (tidak hipertensi) terdapat 28 responden $(41,4 \%)$ diantaranya mengalami obesitas.

Hasil analisa uji statistic Chi Square diperoleh nilai signifikan $\mathrm{p}$ value $=0.004(\mathrm{p}$ value $\leq \alpha 0.05)$. Hal ini dapat diartikan bahwa terdapat hubungan yang signifikan antara Hubungan Obesitas dengan Kejadian Hipertensi pada Masyarakat di Desa Air Tiris Wilayah Kerja UPTD Puskesmas Kampar. Kemudian dari hasil analisis diperoleh nilai OR = 2.8 dapat disimpulkan bahwa responden yang mengalami obesitas beresiko kali lipat memicu terjadinya hipertensi dari pada masyarakat yang tidak mengalami obesitas

\section{PEMBAHASAN}

Berdasarkan pembahasan mengenai Hubungan Obesitas dengan Kejadian Hipertensi pada Masyarakat di Desa Air Tiris Wilayah Kerja UPTD Puskesmas Kampar Tahun 2019 yang ditinjau dari kenyataan yang ditemui dan dibandingkan dengan teori-teori yang ada. Hasil peneltian yang diperoleh dibahas sesuai dengan variabel-variabel penelitian sebagai berikut :

\section{Analisa Bivariat}

\section{Hubungan Obesitas dengan Kejadian Hipertensi pada Masyarakat di Desa Air Tiris UPTD Puskesmas Kampar Tahun 2019.}

Berdasarkan Tabel 4.2 diatas diketahui hasil tabulasi silang (crosstabs) antara hubungan obesitas dengan kejadian hipertensi pada masyarakat di desa Air Tiris wilayah kerja UPTD Puskesmas Kampar menunjukkan bahwa dari 52 responden kelompok kasus (hipertensi), terdapat 11 responden $(41,5 \%)$ diantaranya tidak obesitas, dan dari 52 responden kelompok kontrol (tidak hipertensi) terdapat 28 responden $(41,4 \%)$ diantaranya mengalami obesitas.

Hasil analisa uji statistic Chi Square diperoleh nilai signifikan $\mathrm{p}$ value $=0.004$ ( $\mathrm{p}$ value $\leq \alpha 0.05)$. Hal ini dapat diartikan bahwa terdapat hubungan yang signifikan antara Hubungan Obesitas dengan Kejadian Hipertensi pada Masyarakat di Desa Air Tiris Wilayah Kerja UPTD Puskesmas Kampar. Kemudian dari hasil analisis diperoleh nilai OR = 2.8 dapat disimpulkan bahwa responden yang mengalami obesitas beresiko kali lipat memicu 
terjadinya hipertensi dari pada masyarakat yang tidak mengalami obesitas

Pada responden yang tidak hipertensi tetapi mengalami obesitas disebabkan oleh penyakit lain seperti kolesterol. Kolesterol yang ada dalam tubuh orang yang obesitas relatif lebih besar dibandingkan dengan orang yang tidak obesitas.Kadar normal kolesterol adalah $\leq 200 \mathrm{mg} / \mathrm{dl}$.Kolesterol terbagi dua yaitu Low Density Lipoprotein (LDL) dikenal kolesterol jahat dan High Density Lipoprotein (HDL) dikenal kolesterol baik.Lemak berlebih akan mengganggu kerja jantung karena menimbulkan timbunan kolesterol dan penyumbatan arteri. Pada kolesterol tinggi, ketika kolesterol berlebihan mengendap pada dinding arteri, maka aliran darah di jantung, otak, dan bagian tubuh lainnya bisa terhambat sehingga akan meningkatkan risiko seseorang terkena penyempitan arteri.Penyebab lainnya yaitu trigliserida yang merupakan macam lemak dalam tubuh yang di dalam cairan darah dikemas dalam bentuk partikel lipoprotein. Apabila kadar total kolesterol, LDL dan trigliserida melebihi batas normal maka dapat menyebabkan penyempitan pada pembuluh darah dan pembuluh darah menjadi kaku.

Pada responden yang mengalami hipertensi tetapi tidak mengalami obesitas disebabkan karena adanya penyakit lain seperticephalgia, migren dan vertigo. Vertigo menjadi tanda gejala penyumbatan darah ke otak sehingga menyebabkan otak kekurangan oksigen.Pada vertigo di tandai dengan gangguan sirkulasi, gangguan sirkulasi darah disebabkan oleh pola makan yang tidak sehat dan tidak pernah berolahraga.Ketika sirkulasi darah tidak lancar maka asupan oksigen pada organ pun tidak sempurna. Sehingga akan menyebabkan komplikasi yang berbahaya.

Ramadhani \& Sulistyorini (2015) menyebutkan bahwa hipertensi tidak hanya disebabkan oleh obesitas melainkan beberapa faktor resiko yang dapat menyebabkan hipertensi, seperti kebiasaan olahraga, kebiasaan merokok, mengonsumsi alkohol, usia, dan riwayat penyakit lainnya. Penderita hipertensi tidak menyadari dirinya menderita hipertensi, sehingga mereka cenderung menjadi hipertensi berat karena tidak menghindari dan mengetahui faktor resikonya.

Marlina (2010) menyebutkan bahwa merokok merupakan penyebab dari hipertensi karena zat kimia dalam tembakau seperti tar, nikotin, dan karbon monoksida yang dapat merusak lapisan dalam dinding arteri sehingga arteri rentan terhadap penumpukan plak.Nikotin dalam tembakau juga membuat jantung bekerja lebih keras karena menyempitkan pembuluh darah untuk sementara dan meningkatkan frekuensi denyut jantung serta tekanan darah.

Penelitian ini juga sejalan dengan penelitian yang dilakukan Nasri (2014) di Desa Dedep Kepulauan Meranti, dimana dari 193 responden sebanyak 105 orang $(54,4 \%)$ mengalami obesitas dan dari 193 responden sebanyak 116 orang $(60,1 \%)$ yang mengalami hipertensi.

Hipertensi juga di sebabkan oleh obesitas karena gaya hidup masyarakat yang mengarah pada gaya hidup modern. Penelitian ini sejalan dengan penelitian (Hasanah dkk, 2016) bahwa mayoritas orang jawa yang menyukai masakan yang manis manis dan bersantan tetapi tidak mengimbangi dengan makanan yang sehat sehingga dapat menimbun lemak di dalam tubuh dan bila hal tersebut di biarkan terus menerus dapat menambah berat badan sehingga lama kelamaan dapat menyebabkan obesitas.

Aktivitas yang yang minim dan terlalu lama duduk disertai sering mengonsumsi makanan berlemak serta pola hidup yang buruk membuat sebagian besar seseorang menjadi obesitas dan hipertensi. Duduk dalam waktu lama juga menyebabkan kadar enzim yang memecah lemak dalam tubuh menurun, sehinga lemak tidak dapat di lisis dalam tubuh dan menyebabkan obesitas. Penyakit lain juga dapat menyerang seseorang yang terlalu lama duduk seperti penyakit jantung dan diabetes. Kurangnya aktivitas fisik dapat menyebabkan seseorang mengalami serangan 
jantung. Duduk yang lama dapat menyebabkan aliran darah yang menuju ke otak mengalami gangguan (Yeni \& Meivy, 2015).

Menurut asumsi penelitian selain obesitas, hipertensi juga disebabkan oleh jenis kelamin, hal ini didukung oleh karakteristik responden berjenis kelamin perempuan karena lingkar perut merupakan indikator banyaknya penumpukan lemak di daerah abdomen. Semakin besar nilai lingkar perut seseorang, maka semakin banyak pula penumpukan lemak di daerah abdomen. Asumsi penelitian ini di dukung oleh penelitian yang dilakukan oleh Sulastri Delmi dkk (2012).

Pada pria kandungan lemak tubuh yang sehat berjumlah $15 \%$ dari keseluruhan berat badan. Sedangkan pada wanita berjumlah $25 \%$ dari keseluruhan berat badan. Perbedaan ini mencerminkan perbedaan hormonal dan kebutuhan antar jenis kelamin (Barasi M, 2007 dalam Hasanah dkk, 2016).

Natalia, Hasibuan \& Hendro (2014), mengungkapkan bahwa obesitas merupakan faktor resiko terjadinya hipertensi dengan besar resiko sebesar 2,16, artinya responden yang obesitas mempunyai resiko mengalami hipertensi 2,16 kali lebih besar dibandingkan dengan responden yang tidak obesitas (IMT normal) $(\mathrm{p}=0,01 ; 95 \% \mathrm{CI}=$ 1,32-2,24). Hal ini sejalan dengan penelitian setyawati, Susilowati \& Maisya (2017) bahwa ada hubungan antara Indeks Massa Tubuh (IMT) dengan kejadian hipertensi. Wanita yang memiliki IMT diatas normal berisiko 2,05 kali lebih besar untuk memiliki tekanan darah di atas normal dibandingkan wanita yang memiliki IMT normal.

Menurut asumsi penelitian pada masyarakat yang suka minum kopi tiga kali sehari dapat menyebabkan terjadinya hipertensi. Kopi banyak mengandung kafein sehingga dapat mempengaruhi sistem saraf karena semakin besar tubuh seseorang, maka semakin banyak darah yang dibutuhkan untuk menyuplai oksigen dan nutrisi ke jaringan tubuh.Penyebab utama terjadinya hipertensi pada obesitas diduga berhubungan dengan kenaikan volume tubuh, peningkatan curah jantung, dan menurunnya resistensi vaskuler sistemik.

\section{DAFTAR PUSTAKA}

Depkes. (2018). Hipertensi Penyebab Kematian Nomor Tiga. www.dinkes.go.id. Diakses tanggal 06 April 2019.

Irianto Koes. (2015). Memahami Berbagai Macam Penyakit. Bandung : Alfabeta.

Tarigan, dkk. (2018). Pengaruh Pengetahuan, Sikap dan Dukungan Keluarga Terhadap Diet Hipertensi di Desa Hulu Kecamatan Pancur Batu Tahun 2016. Jurnal Kesehatan. Vol II no I.

Hardiansyah \& Supariasa. (2017). Ilmu Gizi: Teori dan Aplikasi. Jakarta: EGC.

Kemenkes. (2017). Sebagian Besar Penderita Hipetensi Tidak Menyadarinya. www.depkes.go.id. Diakses tanggal 06 April 2019.

Dinas Kesehatan Kabupaten Kampar. (2018). Profil Kesehatan Kabupaten Kampar.

Hasil Utama Riset Kesehatan Dasar. (2018). Profil Riset Kesehatan Dasar.

Muhammad H. (2017 ). Obesitas Translasional. Jogjakarta: Gadjah Mada University Press.

Padila. (2013). Asuhan Keperawatan Penyakit Dalam. Yogyakarta : Nuha Medica.

Manuntung Alfeus. (2018). Terapi Perilaku Kognitif Pada Pasien Hipertensi. Malang : Wineka Media.

Yeni. (2017). Hubungan Obesitas dengan Kejadian Hipertensi di Puskesmas Kecamatan Manguharjo Kota Medium tahun 2015. Inovasi. Vol XIX no 2.

Sulastri, dkk. (2015) Hubungan Obesitas dengan Kejadian Hipertensi pada Masyarakat Etnik Minang Kabau di Kota Padang. Majalah Kedokteran Andalas no 2. Vol 36.

Kemenkes RI. ( 2017 ) Profil Kesehatan Kab. Kampar.

Ramadhani \& Sulistyorini. (2015). Hubungan kasus obesitas dengan hipertensi di provinsi jawa 
timur tahun 2015-2016. Jurnal berkala EPIDEMIOLOGI vol 6 no 1

Udjianti. (2010). Keperawatan Kardiovaskuler. Jakarta : Salemba Medika.

Kowalski E Robert. (2010). Terapi Hipertensi. Bandung : Qanita.

Mediaagro. (2009). Solusi Sehat Mengatasi Hipertensi. Jakarta : PT Agromedia Pustaka.

William \& Wilkins. (2011). Memahami Berbagai Macam Penyakit. Jakarta Barat : PT Indeks.

Adriani \& Wijatmaji. (2012). Pengantar Gizi Masyarakat. Jakarta : KENCANA.

Hasdianah dkk. (2014). Gizi, Pemantapan Gizi, Diet, dan Obesitas. Yogyakarta : Nuha Medica.

Sudargo dkk. (2014). Pola Makan dan Obesitas. Yogyakarta : Gadjah Mada University Press.

Sunanto hardi. (2009). Resep Sembuhkan Hipertensi, Obesitas dan Asam Urat. Jakarta : PT Elex Media Komputindo.
Donsu. (2016). Metodologi Penelitian Keperawatan. Yogyakarta : PUSTAKABARUPRESS.

Notoatmodjo. (2010). Metodologi Penelitian Kesehatan. Jakarta : PT RINEKA CIPTA

Hidayat, A. (2012). Riset Keperawatan dan Teknik Penulisan Ilmiah. Jakarta : Salemba Medika.

Hasanah dkk. (2016). Hubungan Obesitas Dengan Kejadian Hipertensi Pada Masyarakat Di Wilayah Rw 13 Dusun Mojosari Desa Ngenep Kecamatan Karangploso vol 1 no 2.

UPT Puskesmas Kampar, (2018). Jumlah Penderita Hipertensi di Wilayah Kerja Puskesmas Kampar. Kampar.

Nasri, (2014). Hubungan Obesitas Dengan Kejadian Hipertensi Pada Masyarakat Usia 40-60 Tahun di Desa Dedep Wilayah Kerja Puskesmas Bandul Kabupaten Kepulauan Meranti Tahun 2014. Bangkinang. UPTT Riau. 